\title{
Nephroprotective Activity of the Hydro-alcoholic, Ethanolic Extract and its Fractions of Tukhme Soya (Anethum sowa Roxb.) against Gentamicin Induced Nephrotoxicity in Albino Rats
}

\author{
Khatoon Rizwana', Aslam Mohammad ${ }^{1, *}$, Chaudhary Shahid Shah ${ }^{2}$, Nazeem Fahamiya ${ }^{3}$, Mohamed Shiffa ${ }^{3}$ \\ 'Department of Ilmul Advia (Pharmacology), School of Unani Medical Education and Research, Jamia Hamdard, New Delhi, INDIA. \\ 2Department of Ilmul Saidla (Pharmacy), School of Unani Medical Education and Research, Jamia Hamdard, New Delhi, INDIA. \\ ${ }^{3}$ Department of Study in Unani, Institute of Indigenous Medicine, University of Colombo, Rajagiriya, SRI LANKA.
}

\begin{abstract}
Background: Nephrotoxicity is an emerging health issue in many countries due to exogenous or endogenous toxicants. Many drugs are responsible for causing renal damage including antibiotics such as aminoglycoside, cisplatin, etc. Meanwhile some herbs are traditionally used to treat kidney disorders due to their nephroprotective properties. One of them is Tukhme-soya (Seed of Anethum sowa) from family Umbelliferae. This study aims to evaluate the Tukhm-e-soya in gentamicin induced nephrotoxic kidney models in Albino rats. Methods: The rats were divided in to eight groups and each group was comprised of six rats. Group I-VIII were control, toxic, hydro-alcoholic, ethanolic, petroleum ether, chloroform, acetone, aqueous groups respectively. $1 \%$ carboxy methyl cellulose was used as control and gentamicin was used as toxicant. Duration of the study was 8 days. Serum creatinine (S.Cr), Blood Urea Nitrogen (BUN), histopathological studies of kidneys, and lipid peroxidation (LPO), were evaluated. Results were analyzed using one-way analysis of variance followed by Dunnett's post hoc test. Results: BUN, S.Cr and LPO levels were significantly increased
\end{abstract}

in toxicant group when compared with control. Groups III - VIII showed significantly lower values close to control group in these parameters. Study revealed that it has a potent antioxidant activity which may be responsible for its nephroprotective actions. Conclusion: Therefore, it is concluded that all the extracts and fractions of Tukhme soya were effective in nephroprotection but acetone fraction, hydroalcoholic and chloroform fractions were more effective than other groups.

Key words: Nephroprotective, Tukhm-e-soya, Gentamicin, Histopathology, Lipid peroxidation.

Correspondence

Prof. Mohd Aslam

Department of IImul Advia (Pharmacology), School of Unani Medical Education and Research, Jamia Hamdard, New Delhi-110062, INDIA.

Email id: kmaslam@rediffmail.com

DOI: 10.5530/jyp.2022.14.10

\section{INTRODUCTION}

Tukhme Soya (Seed of Anethum sowa) belongs to family Umbellifereae. It is commonly known as Indian dill or dill seeds. In India dill is cultivated as seed spice and vegetable crop. It is useful in food as spice, vegetable and fragrant including medicinal value. ${ }^{1,2}$

According to Unani medicine, it has diuretic, analgesic, antiinflammatory, anti-spasmodic, carminative, lithotriptic, hypnotic, wound healing, emmenogogue, properties. ${ }^{3-7}$ Further, it possesses anti-carcinogenic, insecticidal, antioxidant, anti-infertility, analgesic (dysmenorrhea), and antimicrobial activities as well. ${ }^{8-10}$

Acute Kidney Injury (AKI) is a common form of acute renal disease results from various causes predominantly, misuse of drugs causing nephrotoxicity is the third common cause. ${ }^{11}$ Aminoglycosides are the common group of drugs used to treat various infectious diseases caused by gram negative bacteria, but the effect of its treatment causes drug induced nephrotoxicity. ${ }^{12}$ Among the aminoglycoside group, gentamicin is more frequently used, and therefore, it is responsible for $10-20 \%$ of all cases of AKI. ${ }^{11}$

Reactive oxygen species (ROS) is formed when nephrotoxicity induced by gentamicin and other toxicants in the kidney. ROS is responsible for renal injury due to initiation of cellular damage and necrosis resulting formation of hydrogen peroxide superoxide anion, and hydroxyl anion in mitochondria of kidney. ${ }^{13,14}$ Protein de-maturation, peroxidation of membrane lipids, and DNA damage are the mechanisms involved in kidney damage. ${ }^{15,16}$
Though there are a lot of models for induction of acute renal failure, gentamicin at a dose of $100 \mathrm{mg} / \mathrm{kg} / \mathrm{day}$, ip for 5 consecutive days, is most commonly used model nowadays. It closely mimics the antibiotic induced dysfunction in renal function in clinical setup. ${ }^{17}$

Dill seeds contain many chemical constituents which are having antiinflammatory, antioxidant action, and it has been widely used in the renal conditions by the Unani scholars, it can be assumed that it would prevent the nephrotoxicity. Hence, the aim of this study is to evaluate the nephroprotective activity of Indian dill seeds in the animal model.

\section{MATERIALS AND METHODS}

\section{Procurement and Authentication of the Drug Anethum} sowa

Anethum sowa Roxb. was procured from Azad Nagar Market, local market of Delhi and authenticated by Dr. Sunita Garg, National Institute of Science Communication and Information Resources (NISCAIR), New Delhi. A voucher specimen was deposited in the herbarium of NISCAIR, New Delhi (Authentication number NISCAIR/RHMD/ Consult/2019/3405-06).

\section{Preparations of Extract}

Hydro-alcoholic extract of Anethum sowa Roxb. (HAE) was prepared by the method of Soxhlation. Solvent was recovered and extract was dried on water bath. The percentage was calculated after weighing the extract. 
Using Soxhlet apparatus, ethanolic extract of Anethum sowa Roxb. was prepared. The extract was weighed, and the percentage yield was calculated. Then, this total ethanolic extract (TEE) was used to fractionate into Petroleum ether fraction (PEF) by reflux method. Solvent was retrieved and dried extract was obtained.

Insoluble remaining part of the total ethanolic extract in the flask further fractioned with chloroform as mentioned earlier and by using reflux method, and dried chloroform fraction (CHF) was obtained.

Residue of total ethanolic extract remained after the above process further fractioned with acetone through refluxed method, regained the remaining acetone from the extract and the extract was dried to obtain Acetone fraction (ACF).

In the last step of fractionation, distilled water was used to dissolve the insoluble remains of the total ethanolic extract and using reflux method, Aqueous Fraction (AQF) and its final dried weight were obtained.

\section{Experimental Study}

Data was obtained from laboratory-based studies by using pathogen free albino rats of either sex (male or female) weighing between 150-250 g and 6 to 8 weeks old. These animals were obtained from Central Animal House Facility of Jamia Hamdard, New Delhi and kept in the standard animal facility at room temperature $\left(25 \pm 2^{\circ} \mathrm{C}\right)$ with $12 \mathrm{hr}$ light-dark cycle and was given free access to food (standard pellet diet) and tap water.

All experiments were carried out in accordance with the guidelines for the care and use of laboratory animals, laid down by the committee for the purpose of control and supervision of experiments in animals (CPCSEA), Ministry of Social Justice and Empowerment, Govt. of India, Jan 2000. Ethical clearance was approved by the Institutional Animal Ethics Review Committee, Jamia Hamdard, New Delhi (project number 1732 date 08/03/2017).

\section{Drugs and Chemicals}

Gentamicin was procured from Cadila Healthcare Ltd (Mumbai, India) and all the other chemicals used were of analytical grade.

\section{Experimental design}

The rats were divided into eight groups with six rats in each group. Hydro-alcoholic extract (HAE), total Ethanolic extract (TEE), Petroleum ether fraction (PEF), Chloroform fraction (CHF), Acetone fraction (ACF) and Aqueous fraction (AQF) of total ethanolic extract were suspended in $1 \%$ carboxy methyl cellulose (CMC). Animals were identified by cage number and marked on tail individually. The body weight of the animals was measured at day 0 . The groups, interventions, route of administration, dose, protocol duration and number of animals are given in Table 1.

\section{Biochemical assays}

After the completion of experimental work (8 days of experimental study), on the $9^{\text {th }}$ day animals of all the groups were weighed, anaesthetized with anesthetic ether and sacrificed. Collection of blood samples were done through cardiac puncture using $2 \mathrm{ml}$ syringe of $21 \mathrm{G}$ and kept the blood in plain vials with proper labeling. Blood samples were centrifuged, and blood serum was separated for the estimation of Blood Urea Nitrogen (BUN) and S. creatinine, according to the standard methods. ${ }^{18,19}$

\section{Histopathological Assessment of Rat Kidney}

For histopathological studies kidneys of sacrificed animals were dissected out. Kidney tissues were rinsed by normal saline and secure the tissue in $10 \%$ normal saline dehydrated with $100 \%$ ethanol solution and embedded in paraffin. The tissue of kidney was sectioned in to $4-5 \mathrm{~mm}$

\begin{tabular}{cccccc} 
Table 1: Experimental Protocol. & & & & \\
\hline Groups & Interventions & Route & Dose & Day & Animal \\
\hline Group I & $1 \%$ CMC & PO & $10 \mathrm{mg} / \mathrm{kg} / \mathrm{day}$ & $1-8$ & 6 \\
(Control) & & & & & \\
Group II & Gentamicin & IP & $100 \mathrm{mg} / \mathrm{kg} / \mathrm{day}$ & $3-8$ & 6 \\
(Toxicant) & & & & & \\
Group III & HAE & PO & $126 \mathrm{mg} / \mathrm{kg}$ & $1-8$ & 6 \\
& Gentamicin & IP & $100 \mathrm{mg} / \mathrm{kg} / \mathrm{day}$ & $3-8$ & \\
Group IV & TEE & PO & $49 \mathrm{mg} / \mathrm{kg}$ & $1-8$ & 6 \\
& Gentamicin & IP & $100 \mathrm{mg} / \mathrm{kg} / \mathrm{day}$ & $3-8$ & \\
Group V & PEF & PO & $13.72 \mathrm{mg} / \mathrm{kg}$ & $1-8$ & 6 \\
& Gentamicin & IP & $100 \mathrm{mg} / \mathrm{kg} / \mathrm{day}$ & $3-8$ & \\
Group VI & CHF & PO & $16.74 \mathrm{mg} / \mathrm{kg}$ & $1-8$ & 6 \\
& Gentamicin & IP & $100 \mathrm{mg} / \mathrm{kg} / \mathrm{day}$ & $3-8$ & \\
Group VII & ACF & PO & $9.71 \mathrm{mg} / \mathrm{kg} / \mathrm{day}$ & $1-8$ & 6 \\
& Gentamicin & IP & $100 \mathrm{mg} / \mathrm{kg} / \mathrm{day}$ & $3-8$ & \\
Group VIII & AQF & PO & $8.82 \mathrm{mg} / \mathrm{kg}$ & $1-8$ & 6 \\
& Gentamicin & IP & $100 \mathrm{mg} / \mathrm{kg} / \mathrm{day}$ & $3-8$ & \\
\hline
\end{tabular}

PO- Per oral; IP- Intra Peritoneal

thickness and mounted with haematoxylin-eosin and observed under a photomicroscope.

\section{Kidney Homogenate Analysis}

For the kidney homogenate analysis, a post nuclear supernatant (PNS) was prepared by differential centrifugation method..$^{20}$ Determination of lipid peroxidation (LPO) was measured by analyzing thiobarbituric acid reactive substances (TBARS) by the method of Uchiyama and Mihara (1978) with some alteration. ${ }^{21}$

\section{Statistical Analysis}

Results of all the data are collected and presented as mean \pm SEM. The data was analyzed by one-way ANOVA followed by Dunnet's t-test for comparing control to toxicant and toxicant to various groups using IBM SPSS 20 software. Statistical significance was estimated at the $5 \%$ level.

\section{RESULTS}

The present study was done on albino Wistar rats. 48 animals were randomly divided in to 8 groups treated with different interferences for 8 days. On day 9, animals of all the groups were sacrificed and blood sample were collected for the biochemical analysis to assess gentamicin induced toxicity and protective effect of different extract of Tukhme soya. The toxicant group was containing increased level of Serum creatinine and BUN (1.72 \pm 0.12 and $23.96 \pm 1.21)$ when compared to control group $(0.81 \pm 0.03$ and $11.13 \pm 0.44$ respectively). Test groups III - VIII treated with HAE, TEE, PEF, CHF, ACF and AQF respectively were shown decreased level of S.cr and BUN when compared to toxicant group as given in Table 2 . The level of LPO was a significantly $(P$ value $<0.001$, $<0.01)$ decreased in the different test groups, group III (166.57 \pm 5.11$)$, group IV (155.21 \pm 6.08$)$, group V (194.28 \pm 3.26$)$, group VI (202.89 \pm $5.76)$, group VII $(148.91 \pm 6.5)$ and VIII $(155.51 \pm 2.56)$ when compared to toxicant group.

Group III which received HAE along with gentamicin showed moderate tubular epithelial damage, mild congestion in blood vessels and mild interstitial oedema with no glomerular changes, epithelial desquamation 
Table 2: Effect of HAE, TEE, PEF, CHF, ACF and AQF on S. Creatinine and BUN in gentamicin induced nephrotoxicity.

\begin{tabular}{|c|c|c|c|c|}
\hline Group & Treatment & $\begin{array}{l}\text { S. Creatinine } \\
\text { (mg/dl) Mean } \\
\pm \text { SEM }\end{array}$ & $\begin{array}{l}\text { BUN }(\mathrm{mg} / \mathrm{dl}) \\
\text { Mean } \pm \text { SEM }\end{array}$ & $\begin{array}{l}\text { LPO } \mu \text { moles } \\
\text { TBARS } \\
\text { formed } / \mathrm{h} / \mathrm{g} \\
\text { tissue Mean } \pm \\
\text { SEM }\end{array}$ \\
\hline $\begin{array}{c}\text { Group I } \\
\text { (Control) }\end{array}$ & $1 \% \mathrm{CMC}$ & $0.81 \pm 0$. & $11.13 \pm 0.44^{\star *}$ & $143.18 \pm 2.54^{* *}$ \\
\hline $\begin{array}{l}\text { Group II } \\
\text { (Toxicant) }\end{array}$ & Gentamicin & $1.72 \pm 0.12$ & $23.96 \pm 1.21$ & $210.32 \pm 6.3$ \\
\hline Group III & $\mathrm{HAE}+\mathrm{GM}$ & $0.89 \pm 0.03^{\star *}$ & $11.97 \pm 0.92^{\star *}$ & $166.57 \pm 5.11^{\star *}$ \\
\hline Group IV & $\mathrm{TEE}+\mathrm{GM}$ & $0.92 \pm 0.02^{\star *}$ & $12.05 \pm 1.27^{\star *}$ & $155.21 \pm 6.08^{* *}$ \\
\hline Group V & $\mathrm{PEF}+\mathrm{GM}$ & $0.92 \pm 0.05^{\star *}$ & $14.75 \pm 1.15^{\star *}$ & $194.28 \pm 3.26^{*}$ \\
\hline Group VI & $\mathrm{CHF}+\mathrm{GM}$ & $0.94 \pm 0.04^{* *}$ & $13.70 \pm 1.40^{* *}$ & $202.89 \pm 5.76^{\mathrm{ns}}$ \\
\hline Group VII & $\mathrm{ACF}+\mathrm{GM}$ & $0.88 \pm 0.14^{* *}$ & $11.57 \pm 1.16^{\star *}$ & $148.91 \pm 6.5^{* *}$ \\
\hline Group VIII & $\mathrm{AQF}+\mathrm{GM}$ & $0.93 \pm 0.06^{* *}$ & $12.62 \pm 1.18^{\star *}$ & $155.51 \pm 2.56^{\star *}$ \\
\hline
\end{tabular}

${ }^{\star} P$ value $<0.01(\mathrm{VS}),{ }^{*} P$ value $<0.05(\mathrm{~S}),{ }^{\text {ns }} P$ value $>0.05(\mathrm{~ns})$

and inflammatory cells infiltration. Same changes are found in group VIII which received AQ fraction of Anethum sowa. Group IV, V and VI which received TEE, PE and $\mathrm{CH}$ fraction of Anethum sowa along with gentamicin showed glomerular changes (mild-moderate), tubular casts (moderate), mild epithelial desquamation, moderate to severe congestion of blood vessels with no tubular epithelial damage, inflammatory cell infiltration and no interstitial oedema. Test group VII which received AC fraction of Anethum sowa showed the following histopathological changes such as mild tubular epithelial damages, mild blood vessels congestion and mild interstitial oedema with no glomerular changes, tubular casts, epithelial desquamation and inflammatory cells infiltration (Table 3). Figure 1 to 8 shows renal tissues of the rats of group I to VIII respectively.

\section{DISCUSSION}

Kidney is an important organ of the body, which has a natural function of excretion of waste products from the body. Apart from this it controls the volume and composition of the body fluids, for water and virtually all electrolytes in the body, balance between intake and output is maintained in large part by the kidneys. Kidneys are most important channel of excretion for majority of drugs and its metabolites, so it always opens up to receive the drugs and other toxins which cause renal damage or renal toxicity. Nephrotoxicity occurs when kidney-specific detoxification and excretion do not work properly due to the damage or destruction of kidney function by exogenous or endogenous toxicants. ${ }^{22}$ There are many nephrotoxins including antibiotics such as aminoglycoside, vancomycin, antifungal such as amphotericin $\mathrm{B}$, immunomodulators such as calcineurin inhibitors, chemotherapeutic agents, cyclosporine, tacrolimus etc. ${ }^{23}$

Clinically, the high dose of gentamicin $(2.5 \mathrm{mg} / \mathrm{kg}$, IM every $12 \mathrm{~h}$ for 7 days) has been shown to produce nephrotoxicity. It has been reported that $30 \%$ of patients treated with gentamicin for more than 7 days show signs of nephrotoxicity. ${ }^{24}$ Oxidative stress is one of the common factors for renal tubular necrosis. Due to limitations of conventional medicine, use of herbal nephroprotective agents having powerful antioxidant activities for lowering the oxidative stress are focused by scientist for nephroprotection. ${ }^{25}$

The present study was done on albino Wistar rats. 48 animals were randomly divided in to 8 groups treated with different interferences for
Table 3: Effect of HAE, TEE, PEF, CHF, ACF and AQF on Histopathological features of kidney in Gentamicin induced renal damage.

\begin{tabular}{|c|c|c|c|c|c|}
\hline \multirow[b]{2}{*}{$\begin{array}{l}\text { Name of the } \\
\text { Group }\end{array}$} & \multicolumn{5}{|c|}{ Histopathological Changes } \\
\hline & 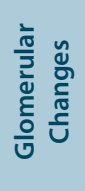 & 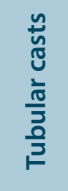 & 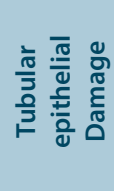 & 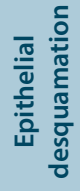 & 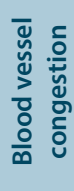 \\
\hline $\begin{array}{l}\text { Group I } \\
\text { (Control) }\end{array}$ & - & - & - & - & - \\
\hline $\begin{array}{c}\text { Group II } \\
\text { (Toxicant) }\end{array}$ & +++ & +++ & +++ & +++ & +++ \\
\hline Group III & - & ++ & + & - & + \\
\hline Group IV & ++ & ++ & - & - & ++ \\
\hline Group V & + & ++ & + & + & ++ \\
\hline Group VI & ++ & ++ & - & + & +++ \\
\hline Group VII & - & ++ & + & - & + \\
\hline Group VIII & - & - & + & - & + \\
\hline
\end{tabular}

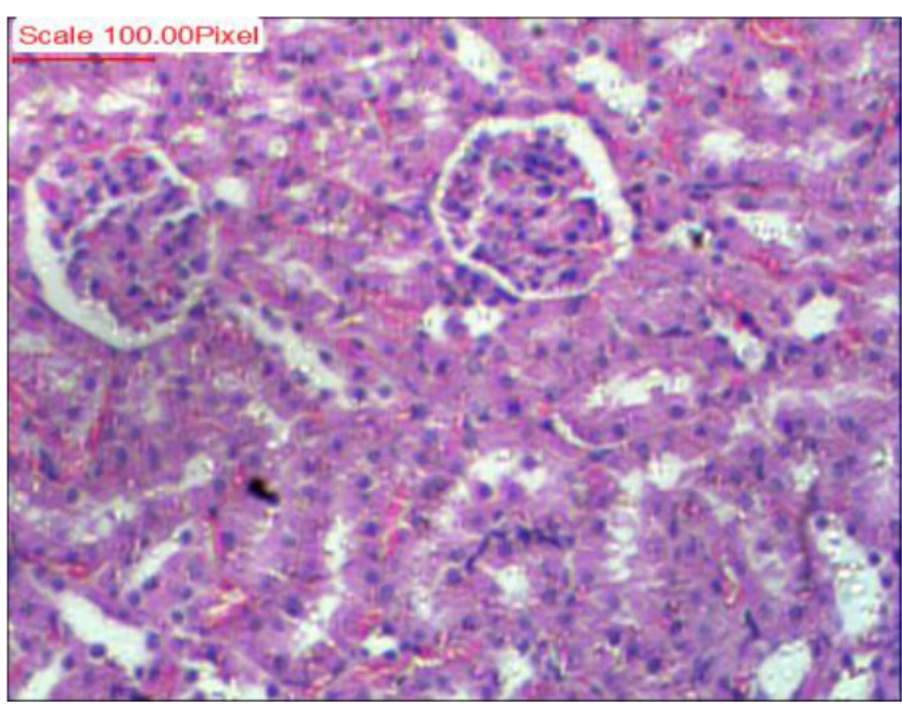

Figure 1: Photomicrograph of renal tissue of rats of control group showing normal kidney cells with intact nucleus ( $1 \%$ CMC in $10 \mathrm{mg}$ distilled water).

8 days. On day 9, animals of all the groups were sacrificed and blood sample were collected for the biochemical analysis to assess gentamicin induced toxicity and protective effect of different extract of Tukhme soya. The function of kidney was estimated on biochemical parameters such as Serum creatinine and BUN. All groups showed lower values of BUN and Serum creatinine nearer to control group but significantly lower in comparison to toxicant group. Acetone fraction treated animal group was showed very low level of S. creatinine and BUN than other groups. These lower values of S. creatinine and BUN indicate the preventive nature of the extracts in renal functions.

There was a significant increase $(P$ value $<.001)$ in the LPO level (210.32 \pm 6.3 ) compared to the normal control group, due to acute nephrotoxicity induced by gentamicin in the kidney homogenate of toxicant group of rats. The increments in ROS production or a reduction in the status of antioxidants and membrane fluidity may causes the 


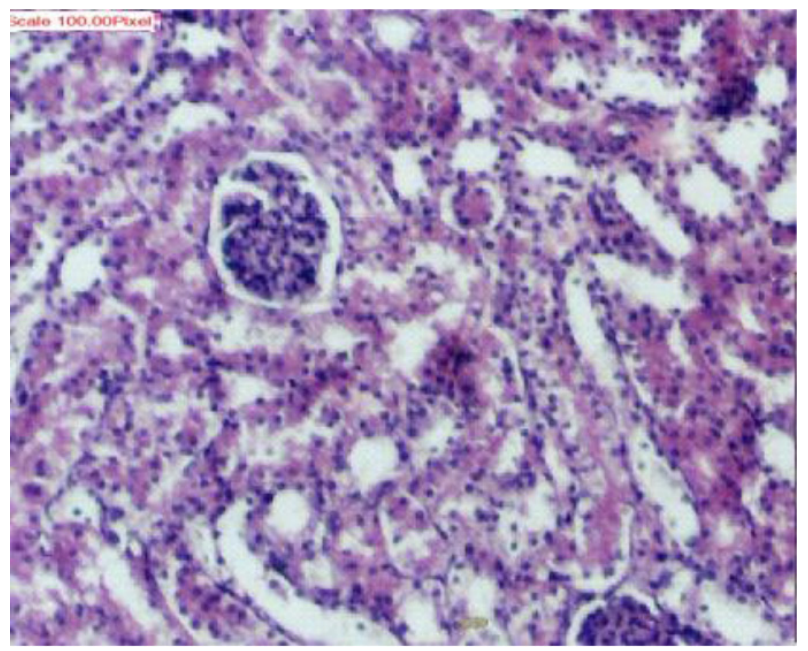

Figure 2: Photomicrograph of renal tissue of rats of toxicant group, treated with Gentamicin (100mg/kg/day).

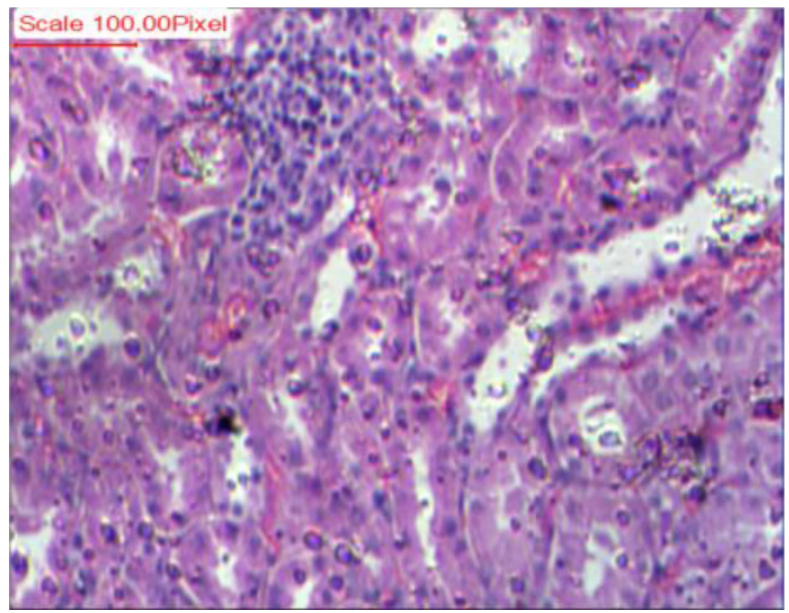

Figure 3: Photomicrograph of renal tissue of rats treated with $\mathrm{HAE}(126 \mathrm{mg} / \mathrm{kg})$ with Gentamicin (100mg/kg/day).

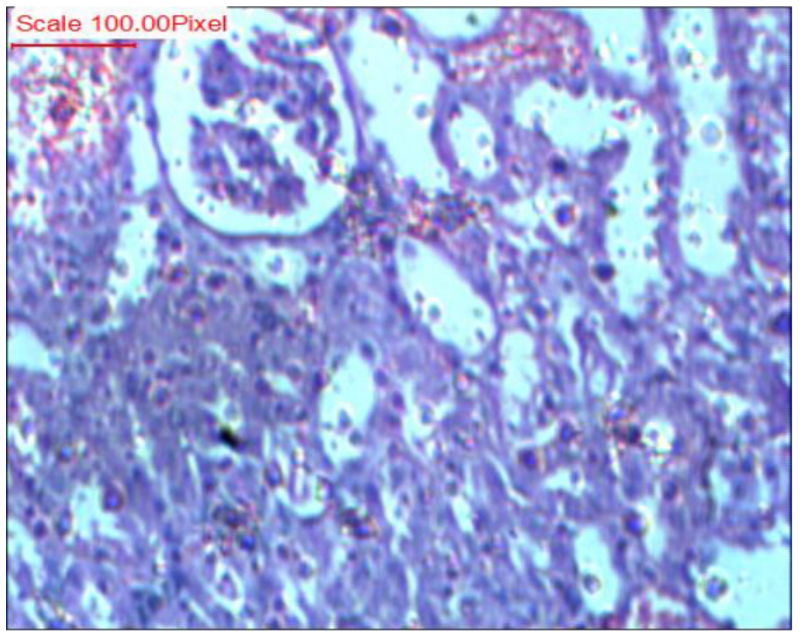

Figure 4: Photomicrograph of renal tissue of rats treated with TEE $(49 \mathrm{mg} / \mathrm{kg})$ with Gentamicin (100mg/kg/day).

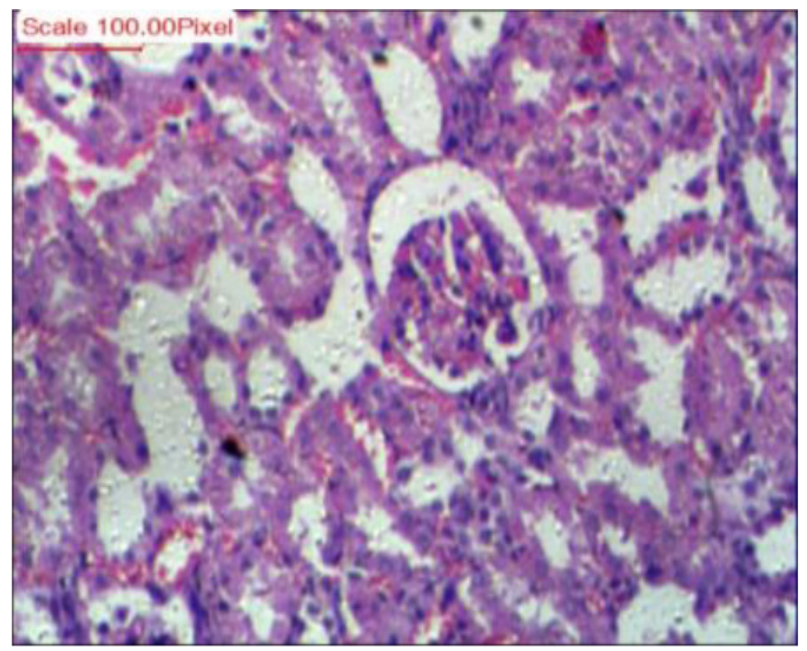

Figure 5: Photomicrograph of renal tissue of rats of PEF $(13.72 \mathrm{mg} / \mathrm{kg})$ with Gentamicin (100mg/kg/day)

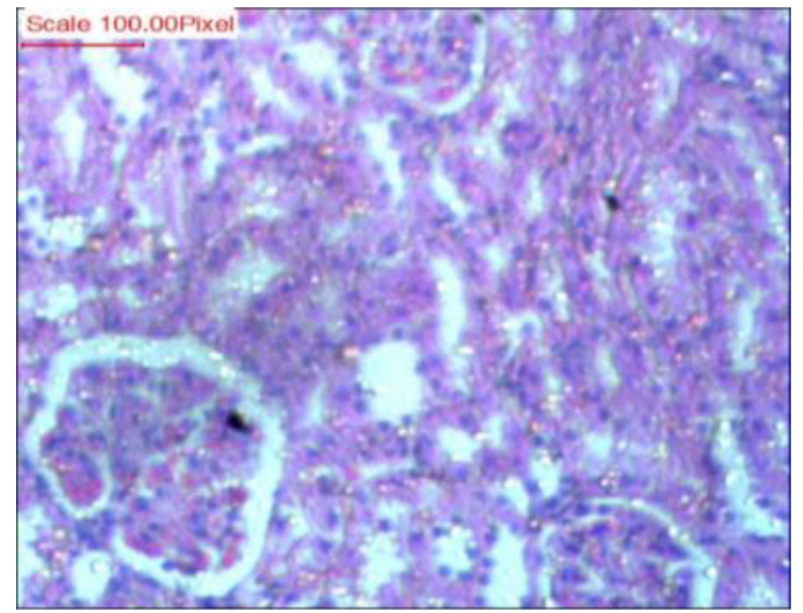

Figure 6: Photomicrograph of renal tissue of rats treated with $\mathrm{CHF}$ $(16.74 \mathrm{mg} / \mathrm{kg})$ with Gentamicin ( $100 \mathrm{mg} / \mathrm{kg} /$ day).

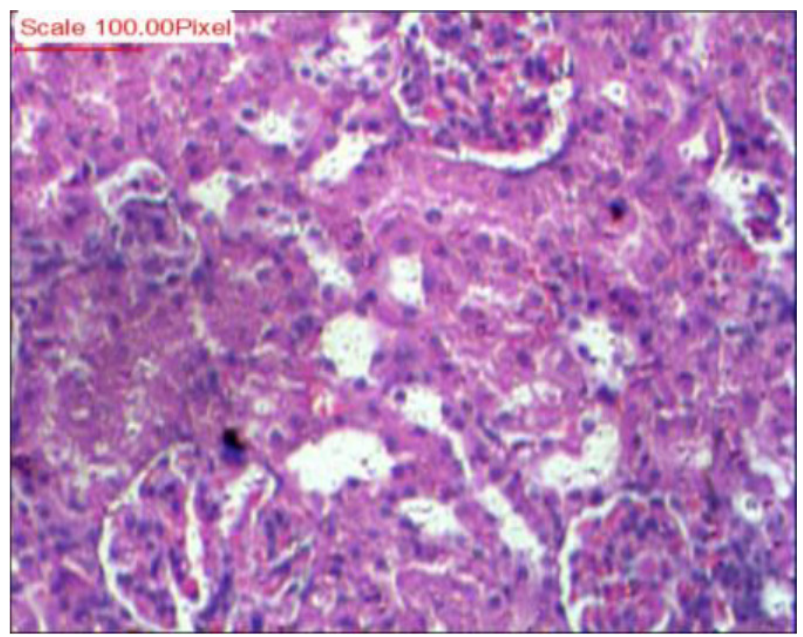

Figure 7: Photomicrograph of renal tissue of rats treated ACF $(9.71 \mathrm{mg} / \mathrm{kg})$ with Gentamicin (100mg/kg/day). 


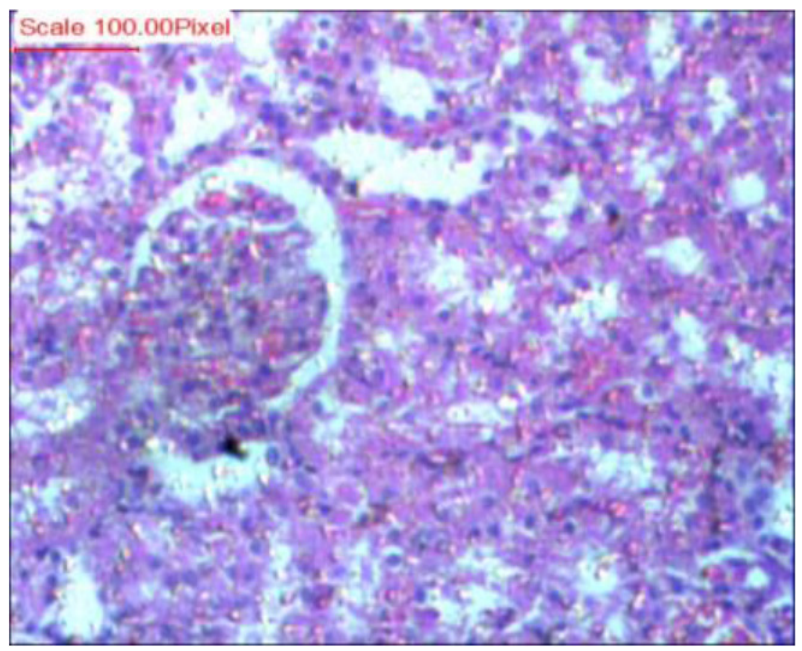

Figure 8: Photomicrograph of renal tissue of rats of AQF $(8.82 \mathrm{mg} / \mathrm{kg})$ with Gentamicin (100mg/kg/day).

enhancement in LPO level which was reported in the present study. LPO level is significantly reduced in all the test groups (group III to group VIII). Group VII (AC fraction) was shown lower value of LPO level among the all-other groups.

Histopathological analysis of kidney of animals in the present study revealed that there were no morphological changes (renal glomeruli bounded by normal capsule and normal proximal, distal and convoluted tubules) in the control group. Gentamicin treated group (toxicant group) showed severe histopathological modifications i.e. glomerular, tubular, and interstitial modifications. The modifications which were seen in this groups, that the bowmen's capsule space increased, vacuolation, dilatation in tubules, shrinkage of glomeruli and inflammatory cells infiltration around the blood vessels etc. Experimental studies have reported that the histopathological changes by gentamicin, are hyper cellularity, blood capillary congestion and shrinkage of glomeruli. ${ }^{13}$ The results of histopathological changes revealed that Acetone fraction of TS showed very less morphological changes (very close to the control group) in kidney tissue of rats as compared to other test groups, while toxicant group showed severe morphological changes in kidney tissues, causes renal dysfunction due to gentamicin induced renal toxicity.

Phyto-constituents of plants contained antioxidant activity or free radical scavenging activity, are able to relieve from various diseases such as inflammatory disorders, cardiovascular systems, cancer and diabetes. ${ }^{26}$ Unani drugs possess nephroprotective properties with no side effects. There are a lot of nephroprotective drugs in Unani system. Tukhm-e-soya (Anethum sowa Roxb.) also one of them, used to improve the urinary system and counterweight the toxicity due to drugs.

Determination of kidney homogenate analysis was done by the estimation of antioxidant enzyme such as LPO. Status of antioxidants and amount of oxidative stress as they play an important role in the etiology of the nephrotoxicity was exhibited in this study. In toxicant group the level of LPO was increased in toxicant group when compared to the normal control, this level decreased in different test group such as HAE, TEE, PEF, CHF, ACF and AQF treated animal group as compared to toxicant group.

\section{CONCLUSION}

The result of this study concludes that Tukhme soya exhibited a protective effect against nephrotoxicity as all the extracts and fractions of Tukhme soya were effective in nephroprotection. However, acetone fraction, aqueous-ethanol and chloroform fractions of Tukhme soya were more effective than other groups. This may be due to its potent antioxidant activity. Therefore, dill seeds are capable to treat the renal damage caused by gentamicin induced nephrotoxicity and besides this, the seed extracts need further experimental studies on large scale on human subjects for the validation of its prominent nephroprotective effect.

\section{ACKNOWLEDGEMENT}

The authors are thankful to Jamia Hamdard, New Delhi for providing laboratory and other facilities.

\section{CONFLICT OF INTEREST}

The authors declare no conflicts of interest

\section{ABBREVIATIONS}

HAE: Hydro-alcoholic extract; TEE: total Ethanolic extract; PEF: Petroleum ether fraction; CHF: Chloroform fraction; ACF: Acetone fraction; AQF: Aqueous fraction; CMC: Carboxy methyl cellulose; AKI: Acute Kidney Injury; ROS: Reactive oxygen species; NISCAIR: National Institute of Science Communication and Information Resources; CPCSEA: control and supervision of experiments in animals; PO: per oral; IP: intra peritoneal; BUN: Blood Urea Nitrogen; PNS: post nuclear supernatant; LPO: lipid peroxidation; GM: Gentamicin; TBARS: thiobarbituric acid reactive substances.

\section{REFERENCES}

1. Chopra RN, Nayer SL, Chopra IC. A Glossary of Indian medicinal plants and supplements, publication and information directorate. New Delhi: CSIR; 1992. P. 216-217.

2. Khatoon R, Aslam M, Chaudhary SS. Ethnobotany and Unani Perspective of Tukhme Soya (Anethum sowa Roxb.). Journal of Drug Delivery and Therapeutics. 2019; 9 (3): 537-42.

3. Ali Ibn e Abbas Majoosi. Kamil us Sana. Ghulam Hasnain Kantoori (Urdu translation), editor. Vol. 3. New Delhi: Idara Kitab us Shifa; 2010.

4. The Unani Pharmacopoeia of India. Vol. VI. New Delhi: CCRUM; 2008.

5. Ibn Baitar. Aljami ul Mufradat Al Aghziya wal Advia. Vol. 3. New Delhi: CCRUM; YNM.

6. Azam Khan. Muhit e Azam. Vol. 3. New Delhi: CCRUM; 2014.

7. Kabiruddin H. Makhzan-ul-Mufradat. New Delhi: Idara Kitab us Shifa; 2010.

8. Saleh-E-In MM, Sultana N, Hossain MN, Hasan S, Islam MR. Pharmacological effects of the phytochemicals of Anethum sowa L. root extracts. BMC Complement Altern Med. 2016;16(1):464. doi:10.1186/s12906-016-1438-9

9. Md Moshfekus Saleh-E-In, Yong Eui Choi. Anethum sowa Roxb. ex Fleming: A review on traditional uses, phytochemistry, pharmacological and toxicological activities. J Ethnopharmacol. 2021; 113967. https://doi.org/10.1016/j. jep.2021.113967.

10. Saleh-e-In MM, Sultana N, Rahim MM, et al. Chemical composition and pharmacological significance of Anethum sowa L. Root. BMC Complement Altern Med. 2017; 17; 127. https://doi.org/10.1186/s12906-017-1601-y

11. Al-Naimi MS, Rasheed HA, Hussien NR, Al-Kuraishy HM, Al-Gareeb Al. Nephrotoxicity: Role and significance of renal biomarkers in the early detection of acute renal injury. J Adv Pharm Technol Res. 2019;10(3):95-9.

12. Sales GTM, Foresto RD. Drug-induced nephrotoxicity. Revista da Associação Médica Brasileira. 2020; 66: s82-90.

13. Nasri H, Nematbakhsh M, Rafieian-Kopaei M. Ethanolic extract of garlic for attenuation of gentamicin-induced nephrotoxicity in Wistar rats. Iran J Kidney Dis. 2013; 7(5): 376-82.

14. Nazeem Fahamiya, Mohd Aslam, Kalim Javid, Aisha Siddiqui, Mohamed Shiffa. Althaea rosea $\mathrm{L}$. ameliorates renal oxidative damage induced by gentamicin in rats, Indian Journal of Traditional Knowledge. 2017; 16(4):694-699.

15. Jain DP, Somani RS. Antioxidant potential of hesperidin protects gentamicin induced nephrotoxicity in experimental rats. Austin J Pharmacol Ther. 2015; 3(2): 1071.

16. Kaur N, Kishore L, Singh R. Attenuation of STZ-induced diabetic nephropathy by Cucurbita pepo L. seed extract characterized by GCMS. J Food Biochem. 2017; 41(6): e12420.

17. Singh AP, Muthuraman A, Jaggi AS, Singh N, Grover K, Dhawan R. Animal models of acute renal failure. Pharmacol Rep. 2012;64(1):31-44. 
18. Ruth SH. Endogenous creatinine in serum and urine. Proc. Soc. Exp.Biol.Med. 1950; 74: 148-150.

19. Kanter MW. Clinical chemistry. Bobber Merill; 1975.

20. Zhou M, Philips MR. Nitrogen Cavitation and Differential Centrifugation Allows for Monitoring the Distribution of Peripheral Membrane Proteins in Cultured Cells. J Vis Exp. 2017;(126):56037. doi:10.3791/56037

21. Mihara M, Uchiyama M. Determination of malonaldehyde precursor in tissues by thiobarbituric acid test. Anal Biochem. 1978; 86(1): 271-8. doi: 10.1016/00032697(78)90342-1. PMID: 655387

22. Kim S, Moon A. Drug-induced nephrotoxicity and its biomarkers. Biomol Ther.
2012; 20(3): 268.

23. Shahrbaf F, Assadi F. Drug-induced renal disorder. J Renal Inj Prev. 2015; 4(3): 57.

24. Mantri AMV, Mathew J, Joseph A, Srinivasan S, Dinakaran SK. Effect of ethanol extract of Sphaeranthus indicus on cisplatin-induced nephrotoxicity in rats. Nat Prod Res. 2012; 26(10): 933-8.

25. Rivera J, Loya A, Ceballos R. Use of herbal medicines and implications for conventional drug therapy medical sciences. Altern Integ Med. 2013; 2(6): 1-6.

26. Kpemissi IM, Eklu KG, Veerapur V, Potârn, Potârniche A, Adi K, Aklikokou K. Antioxidant and nephroprotection activities of Combretum micranthum: A phytochemical, in-vitro and ex-vivo studies. Heliyon. 2019; 5(3): 1-31.

Article History: Received: 19-11-2021; Revised: 28-11-2021; Accepted: 10-12-2021

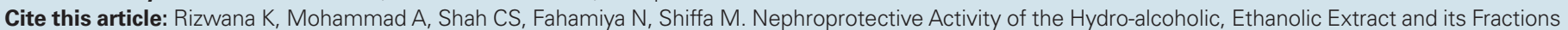
of Tukhme Soya (Anethum sowa Roxb.) against Gentamicin Induced Nephrotoxicity in Albino Rats. J Young Pharm. 2022;14(1):50-5. 